\title{
Revisiting the REDD+ experience in Indonesia Lessons from national, subnational and local implementation
}

\author{
Sandy Nofyanza, Moira Moeliono, Vivi Selviana, Bimo Dwisatrio, Nining Liswanti, Ade Ryane Tamara and Mella Komalasari
}

\section{Key messages}

- In Indonesia, early involvement and support for Reducing Emissions from Deforestation and Forest Degradation (REDD+) has led to numerous achievements, but progress has been slower than anticipated.

- National and subnational REDD+ initiatives are susceptible to political turnover at each election cycle. To ensure its longevity, REDD+ needs to be embedded in national and regional laws, regulations, institutions and other state devices.

- $\quad$ REDD+ institutionalization in Indonesia has focused on technicalities rather than on directly addressing socioeconomic and political drivers of deforestation and forest degradation. The rate of deforestation has decelerated enough to result in two REDD+ payments. However, transformational change in the forestry and broader land-use sector has not progressed far enough.

- $\quad$ REDD+ is inherently multilevel and multisectoral. However, much information, action, knowledge exchange and decision making on REDD+ is concentrated within relatively few organizations. Transformational change requires that other stakeholders and sectors that impact forests get involved.

\section{Introduction}

In this brief we aim to highlight several lessons from the experience of Reducing Emissions from Deforestation and forest Degradation (REDD+) in Indonesia and explore relevant opportunities for future forest-based climate mitigation and adaptation initiatives. We draw on lessons from the ongoing Global Comparative Study (GCS) on REDD+ conducted since 2009 by the Center for International Forestry Research (CIFOR), as well as from other relevant literature on REDD+ implementation in Indonesia.

We distinguish between REDD+ as an outcome (i.e. reduced emissions and deforestation) versus REDD+ as a mechanism (i.e. means to achieve the outcome), in line with Martius et al. (2018). As an outcome, REDD+ has so far been unable to halt global tropical deforestation, but there have been several intermediate milestones while the mechanism was being established (Angelsen et al., 2018). In Indonesia, official national deforestation data show a decline in the annual deforestation rate between 2015 and 2017 (KLHK, 2018b). In early 2019, the Norwegian Government announced that Indonesia would receive, as its first results-based REDD+ payment, USD 56 million for reducing $4.8 \mathrm{MtCO}_{2}$ emissions in 2017 against the 2006-2016 historical baseline (Seymour, 2019). More recently, Indonesia received another performancebased payment - USD 103 million from the Green Climate Fund (GCF) for $20.3 \mathrm{MtCO}_{2}$ emissions reduced between 2014 and 2016 (Kemenkeu, 2020).

Other REDD+ milestones in Indonesia include the creation of national and subnational REDD+ strategies and the establishment of the National REDD+ Agency (BP REDD+), which was integrated into the Ministry of Environment and Forestry (KLHK). REDD+ has also encouraged progressive policy developments, particularly the 'One Map' land-use database and the first-ever moratorium' (now permanent) on the issuance of new concession licenses in primary forests and peatlands (Indrarto et al., 2012, Resosudarmo et al., 2014, Korhonen-Kurki et al., 2017, Astuti and McGregor, 2015). In addition, REDD+ processes

\footnotetext{
1. The moratorium came into effect in 2011 and was regularly renewed every other year. Last year it was made permanent by a Presidential Instruction (Inpres) no. 5/2019.
} 
work alongside indigenous (or adat) communities' aims to strengthen their rights to forests (Astuti and McGregor, 2015, Duchelle et al., 2019). One significant achievement of the country's indigenous movement was the 2012 Constitutional Court Decision no. 35, which withdrew the inclusion of customary forests as part of state forests - expanding the legal basis for advancing an adat claim within the state forest area.

More than a decade ago, REDD+ was envisioned as a catalyst for transformational change ${ }^{2}$ towards sustainable climate mitigation in the forestry and land use sector (Brockhaus and Angelsen, 2012, Di Gregorio et al., 2015, Angelsen et al., 2018). Since then, two major developments have emerged: a new global climate architecture in the 2015 Paris Agreement requiring countries to detail their emissions reductions in Nationally Determined Contributions (NDCs); and new ideas for REDD+ implementation such as situating REDD+ within jurisdictional approaches to low-emission development and the need to engage non-state actors, particularly the private sector (Angelsen et al., 2018). In the REDD+ arena, transformational change requires: (i) strong collaboration and information exchange across levels, sectors, and social divisions; (ii) active participation of diverse stakeholders in REDD+ processes; and (iii) alternative ideas to business-as-usual gaining traction in the policy domain (Moeliono et al., 2020). But there are barriers to transformational change. Deforestation and forest degradation remain deeply entrenched, as powerful and well-resourced organizations strive to maintain businessas-usual practices, hampering the formulation of optimal policy choices (Erbaugh and Nurrochmat, 2019, Moeliono et al., 2020). To better understand REDD+ progress in Indonesia, we focus on selected key challenges and lessons from REDD+ implementation at national and subnational levels. We then present the dynamics of REDD+ as a multilevel and multiparty process, and present evidence from multistakeholder forums that attempt to enhance coordination among sectors.

\section{REDD+ at the national level}

Indonesia supported the global REDD+ agenda early on by proactively aiming to be 'REDD+ ready' by 2013 (Indrarto et al., 2012). The 2007 United Nations Framework Convention on Climate Change (UNFCCC) meeting in Bali

2 Defined as a "shift in discourse, attitudes, power relations and deliberate policy and protest action that leads policy formulation and implementation away from business-as-usual policy approaches that directly or indirectly support deforestation and forest degradation" (Brockhaus and Angelsen, 2012: 16-17).
(COP 13) helped lay the groundwork for implementing REDD+ (Resosudarmo et al., 2014). Indonesia continues to receive support from the UN REDD+ Programme, the World Bank-led Forest Carbon Partnership Facility (FCPF), and a bilateral agreement (Letter of Intent, Lol) with the Government of Norway (Ochieng et al., 2018). More specifically, the Lol envisioned three phases of REDD+ forest governance reform in Indonesia (Caldecott, 2019): (i) institutional development and capacity building; (ii) forest management and governance transformation; and (iii) implementation of results-based emissions reduction.

At the national level, the Ministry of Environment and Forestry (KLHK) made rapid progress on several fronts: it established a new ministerial taskforce to accelerate the recognition of traditional land rights (Caldecott et al., 2018) and developed a province-wide results-based emissions reduction program, in close collaboration with East Kalimantan's government. The national REDD+ architecture ${ }^{3}$ is now shaping up. For instance, the modalities for the national measurement, reporting and verification (MRV) system are operational (KLHK, $2018 a)^{4}$, and the system has reached the point of 'deep institutionalization'5 (Ochieng et al., 2018) due to the recognized importance of harmonized maps, the early contribution from BP REDD+, and the presence of a multisectoral initiative called the Indonesian National Carbon Accounting System (INCAS) in the mid-2010s (Korhonen-Kurki et al., 2015). Moreover, KLHK has established safeguard information systems for REDD+ (SIS REDD+), which are now operational in Jambi, and in East and West Kalimantan (Tacconi and Muttaqin, 2019). However, human and technical capacity for MRV and SIS REDD+ at subnational levels remains weak and unevenly distributed (Ochieng et al., 2018, Ekawati et al., 2019).

Indonesia submitted an updated national forest reference emission level (FREL) in 2016. It covers emissions from deforestation, forest degradation and peat decomposition. The FREL was set at $0.57 \mathrm{GtCO}_{2}$ e $\mathrm{yr}^{-1}$, using 1990-2012 as the reference period, and was used for evaluating REDD+

3 The five components of Indonesia's REDD+ architecture (Ekawati et al., 2019) are: (i) REDD+ national strategies and action plan; (ii) national and subnational-level FREL; (iii) safeguards system; (iv) MRV systems; and (v) funding system and benefit-sharing mechanism.

4 The related regulations on MRV are set under three Minister of Environment and Forestry Decrees (Permen LHK) established in 2017: no. P.71 (on the national registry), no. P.72 (on MRV implementation guidelines), and no. P.73 (on GHG inventory guidelines).

5 According to Ochieng et al. (2018), 'deep institutionalization' occurs when four conditions are satisfied: (i) MRV and its ideas are formed into policy discourses at the national level; (ii) new actors and (iii) additional resources are mobilized; and (iv) new rules to formally anchor MRV and regulate the role of actors are present. 
performance against actual emissions for the 2013-2020 implementation period (KLHK, 2016). However, the design of the FREL is criticized by some, including several GCF board members, due to the potential overestimation of emissions reduced or avoided based on long reference periods as baselines (Jong, 2020b). Given Indonesia's extensive high-carbon-reservoir tropical wetlands, one major area for improvement in the FREL and national MRV systems is the refinement of greenhouse gas (GHG) accounting in peatlands and mangroves (e.g., peatland fires, non-CO2 emissions, and post-conversion/-intervention removals). A strengthened FREL and more robust MRV system could generate returns in the form of results-based payments. CIFOR is currently exploring ways to improve the accuracy of the FREL through the generation of better emission factors and activity data, for example by incorporating underrepresented land cover types such as peatland and mangroves.

The government has also established a new public service agency - the Environmental Fund Management Agency (BPDLH) - to manage REDD+ payments (e.g. from Norway and G(F) and other upcoming climate funding. ${ }^{6}$ Designed to be co-managed by the Ministry of Finance and KLHK, it is expected to increase accountability and transparency in climate fund management and streamline the allocation process (Atmadja et al., 2018).

\section{REDD+ meets Indonesia's political economy}

In Indonesia, REDD+ is being implemented within a challenging context of a resource-rich economy, unclear land rights and allotment of concessions, and insufficient protection for indigenous communities.

Decentralization, beginning with the downfall of Soeharto in 1998, prompted new political struggles between national, provincial and district governments over the right to manage and benefit from land-based natural resource sectors (Libert-Amico and Larson, 2020, Barr et al., 2006). Decentralization can empower subnational actors to bring about environmentally responsible economic development; however, in Indonesia ambiguous decentralization rules have led to illegality, corruption and increased deforestation (LibertAmico and Larson, 2020).

6 BPDLH is a manifestation of the Government Regulation (PP) no. 46/2017 (on Economic Instruments for the Environment) and the Presidential Regulation (Perpres) no. 77/2018 (on Environmental Fund Management).
In Indonesia, REDD+ found a resource-rich economy in which political and economic policies are oriented towards exploitation of those resources (Myers and Ardiansyah, 2014). Some of the major deforestation drivers, such as agricultural and urban expansion, are outside of the forestry sector (Indrarto et al., 2012, Di Gregorio et al., 2012). The recently passed Bill on Job Creation (Omnibus Law) exemplifies the government's increasing tendency towards neoliberal economic development through deregulation.? The Omnibus Law will simplify the land-based business permit process by replacing the mandatory 'environmental permit' (izin lingkungan) with a weaker 'environmental approval' (persetujuan lingkungan), potentially limiting both public participation in environmental impact assessments and the public's ability to challenge the permit in court (ICEL, 2020). Observers have raised concerns that the Omnibus Law is sidelining environmental concerns in pursuit of economic expansion (Jong, 2020a).

REDD+ in Indonesia must also deal with unclear land rights and their allotment, combined with weak law enforcement and insufficient protection of indigenous rights. Some deforestation and forest degradation have occurred illegally (or semi-legally), even within areas that have been zoned for conservation (Luttrell et al., 2012). The forest and peatland moratorium introduced in 2011 was rife with delays and technical shortcomings and thus was unable to fully prevent forest conversion (Murdiyarso et al., 2011, Seymour, 2012). For example, the Lol used the term use 'natural forest' - which the Indonesian Government does not recognize - whereas the moratorium regulation used the term 'primary forest'. In addition, adat land recognition, as mandated by the constitutional court ruling, is progressing slowly and unevenly (Astuti and McGregor, 2016), likely because of opposition from within government and private companies, who stand to lose control of - and revenues from - forests (Moeliono et al., 2017).

\section{New arrangement of key institutions and REDD+ institutionalization}

REDD+ progressed rapidly until 2014, as BP REDD+ worked to put the national REDD+ architecture in place (Korhonen-Kurki et al., 2018). However, progress

\footnotetext{
7 The Omnibus Bill on Job Creation (Law no. 11/2020) can be found online: https://www.setneg.go.id/view/index/undang_undang_republik_ indonesia_nomor_11_tahun_2020_tentang_cipta_kerja.
} 
slowed down in early 2015 when President-elect Joko Widodo disbanded BP REDD+ and merged it with the new KLHK. This restructuring was opposed by BP REDD+ leadership, which argued that it would violate the Lol on the Directorate General for Climate Change (DG PPI). As a directorate, as opposed to a national agency, it was difficult to coordinate REDD+ and climate change issues beyond the forestry sector at a sufficiently high enough administrative level. Nevertheless, KLHK (through the DG PPI) resumed the REDD+ institutionalization process at the end of 2016 (Korhonen-Kurki et al., 2018), and by 2019 it was regarded as the most influential REDD+ actor in the country (Moeliono et al., 2020). The government has initiated several efforts to improve forest governance in general and REDD+ in particular. Yet, REDD+ institutionalization is still mostly focused on technical issues (e.g. Ministerial Regulation no. P.70/2017 concerning procedures for REDD+ implementation) and has only indirectly addressed underlying socioeconomic and political drivers of deforestation. This exemplifies a process of projectification ${ }^{8}$, not transformational change (Li, 2015, Moeliono et al., 2020).

Importantly, the government initiated other programs that, while not specifically aimed at reducing deforestation, will potentially have a big impact on how forests are governed. The Agrarian Reform and Social Forestry programs aim to provide access to forestland for people living near or within forest boundaries in order to improve their wellbeing, achieve more equitable distribution of land, and thereby improve forest governance. Under the Agrarian Reform, 4.1 million ha of forest will be allocated to individuals and converted to agriculture. Under Social Forestry, local communities will be given use rights or, in the case of customary communities, gain recognition of their traditional rights to 12.7 million ha of forest land. However, under Social Forestry the rights holders will bear the duty of maintaining the forest. Like REDD+, it remains focused on technicalities designed at central level with too little involvement at district level where the action happens. Both initiatives could be more purposefully linked to efforts to reduce deforestation.

The rise and fall of BP REDD+ is a manifestation of Indonesia's longstanding political culture, which normalizes the creation of an ad hoc, multisectoral task force as a quick fix to an emerging challenge (Luttrell et al., 2014). The creation of the Peat Restoration Agency (BRG) - with its five-year mandate - as a response to the

8 Defined as a "process through which plans for systematic, longterm change collapse into incremental, simplified solutions" (Li, 2015; Moeliono et al., 2020) catastrophic 2015 peatland fires is another example. Yet, as shown by the case of BP REDD+, such ad hoc institutions are inherently unsustainable and are vulnerable to the shifting development priorities of a changing political leadership.

A key lesson from this experience is that governance reforms required for REDD+ need to be meaningfully mainstreamed within formal institutional structures. This can be done by capturing the wider political support of parliament, civil servants, business and the public to ensure long-lived, sustainable reforms - a challenge that has proven to be gargantuan (Luttrell et al., 2014). Today, half a decade since REDD+ was put fully under KLHK's domain through the DG PPI, we find an institutionalization process that, thus far, reflects incremental changes instead of transformational ones. Business-as-usual interests are still dominant (Moeliono et al., 2020).

\section{REDD+ at the subnational level}

Although originally conceived at the national level and implemented through projects, subnational jurisdictional REDD+ programs have grown over time (Duchelle et al., 2019). Jurisdictional approaches to REDD+ are holistic forest- and land-use strategies applied to an entire administrative territory, with a high level of governmental involvement (Boyd et al., 2018, Stickler et al., 2018). The advancement of subnational jurisdictional REDD+ programs across the tropics has been supported by the Governor's Climate and Forest Task Force (GCF-TF), an international network of subnational governments with commitments to reducing deforestation. ${ }^{9}$

The progress of jurisdictional REDD+ programs in Indonesian provinces is not uniform. At the forefront of jurisdictional REDD+ are East Kalimantan and Jambi, which were selected as pilots for province-wide emissions reduction programs under the FCPF-Carbon Fund and BioCarbon Fund, respectively. Other provincial governments like South Sumatra and West Kalimantan have followed suit by establishing similar green growth plans (in 2015 and 2018, respectively), and West Papua declared itself the world's first 'Sustainable Development Province' with the issuance of a Special Regional Regulation (Perdasus no. 10/2019).

9 Seven Indonesian provinces are members of GCF-TF: Aceh, Central Kalimantan, East Kalimantan, North Kalimantan, West Kalimantan, Papua, and West Papua. 


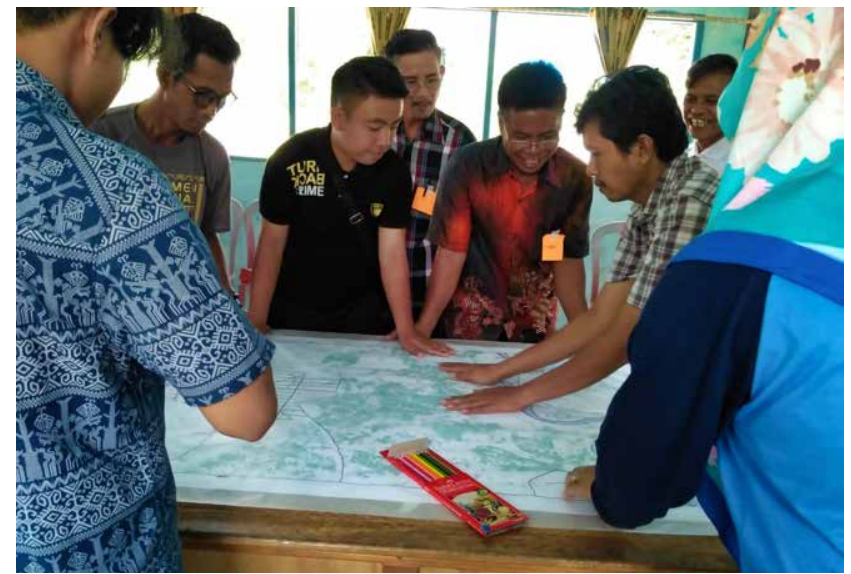

Participatory mapping exercise during village survey, Central Kalimantan.

Photo by Karlina/CIFOR

Jurisdictional REDD+ is not exclusive to the provincial level. One of the first jurisdictional REDD+ initiatives in Indonesia, the Berau Forest Carbon Program (BFCP) was established in 2009 in Berau Regency, East Kalimantan (Anandi et al., 2014b, Hovani et al., 2018). Further, in 2017 eight district governments established the Sustainable Districts Association (Lingkar Temu Kabupaten Lestari or LTKL), a collaborative forum focusing on sustainable land use through collective action. ${ }^{10}$ Its members have committed to reducing deforestation, increasing local income, and alleviating poverty (Boyd et al., 2018). Finally, LTKL led the initiative to institutionalize jurisdictional approaches in the national mid-term development plan (Rencana Pembangunan Jangka Menengah Nasional, or RPJMN) and along with Institut Pertanian Bogor (IPB University), is leading the development of technical guidelines.

\section{Nesting local-level REDD+ projects into higher-level jurisdictional programs}

Following the 2007 UNFCCC COP, there was a rapid growth of local REDD+ projects globally (Simonet et al., 2015). By 2009 Indonesia had the largest number of REDD+ projects worldwide, with 24 REDD+

10 At the time of writing, there are 12 districts registered as members of LTKL ( 6 from Sumatra, and 3 each from Sulawesi and Kalimantan). projects and four REDD+ readiness activities (WertzKanounnikoff and Kongphan-Apirak, 2009), and by 2018 this grew to 44 projects. Six of these projects are studied under CIFOR's GCS REDD+ (Sills et al., 2014).

The national REDD+ architecture requires REDD+ projects to be nested into national or subnational jurisdictions, in order to harmonize carbon accounting (Angelsen et al., 2008). At present, however, this has not been achieved and no nesting strategy has been agreed (Ekawati et al., 2019). Without this harmonization, the country risks double counting emissions reductions (Lee et al., 2018), particularly if local REDD+ projects offer and trade carbon offset credits internationally (e.g. the Katingan and Rimba Raya REDD+ projects in Central Kalimantan; (Indriatmoko et al., 2014a, 2014b). However, achieving such harmonization is challenging given the high transaction costs (Angelsen et al., 2008) and gaps in both resources and capacities among national, subnational and local levels.

\section{Private sector commitments to zero deforestation and jurisdictional REDD+: The palm oil sector}

There is an opportunity to link REDD+ finance to private sector sustainability initiatives at the jurisdictional scale. For private actors in the palm oil sector - a major contributor to the Indonesian economy - sustainability commitments manifest in three ways: (i) adoption of voluntary sustainable standards (VSS); ${ }^{11}$ (ii) sector-wide supply-chain-focused interventions (e.g. protection of high-conservation value areas); and (iii) a mix of supply chain and territorial initiatives at jurisdictional level or 'zero-deforestation jurisdictional approaches' (Pacheco et al., 2018). On paper, corporations' commitments hold significant potential as six major signatories to zero deforestation commitments account for 60 percent of palm oil output in Indonesia (Innovation Forum, 2016). However, private sector initiatives have been implemented relatively slowly, have their own limitations; for example, not all oil palm producers are able to adopt VSS (Pacheco et al., 2018), and are challenged by the government's responses who concerned that the commitments would restrict economic growth from oil palm and drive smallholders and small-scale producers out of business (Pirard et al., 2015).

11 Voluntary Sustainable Standard (VSS) relevant to the palm oil sector include the Roundtable on Sustainable Palm Oil (RSPO) and Rainforest Alliance. 
Jurisdictional approaches, in the case of sustainable palm oil, largely revolve around issues of supply chain traceability, cheaper implementation costs, and political buy-in (Pirard et al., 2017). There has been growing interest at the subnational level towards foreign investments that align with international sustainability standards. For example, some districts in West, East, and Central Kalimantan have built formal partnerships with multinational corporations for sustainable commodities (Stickler et al., 2018). Meanwhile, others such as West Kotawaringin and Seruyan Regencies of Central Kalimantan and the Musi Banyuasin Regency of South Sumatra have also committed to jurisdiction-wide oil palm certification initiatives (Pirard et al., 2017, Luttrell et al., 2018, Irawan et al., 2019).

East Kalimantan's jurisdictional emissions reduction program under FCPF is promoting the protection of 640,000 hectares of high-conservation value forests (HCVF) located inside oil palm concessions. This is gaining both executive and legislature support, as manifested in the Provincial Regulation (Perda) no. 7/2018 on Sustainable Plantations. Simply put, this REDD+ commitment will prevent companies from legally converting any more of their concession lands. Further, in Jambi, the BioCarbon Fund initiative is entertaining the idea of encouraging private sector participation in ecosystem restoration and conservation activities outside their concessions by nesting project-level carbon credits within Indonesia's NDC (IFC, 2018). If this (challenging) nesting process is achieved, it would be a step forward for Indonesia to have a GHG accounting system that is harmonized across administrative levels. Encouraging companies to contribute beyond undertaking conservation efforts within their own concessions, and beyond the HCVF protection promoted under the East Kalimantan's FCPF, would be another significant achievement.

\section{Selected challenges of jurisdictional REDD+ in subnational Indonesia}

Overall, despite commitments made at the subnational level, reducing deforestation remains a challenge. A recent study by Stickler et al. (2020) shows that, at the current deforestation rate, seven Indonesian provincial signatories to 2014 Rio Branco Declaration (RBD) ${ }^{12}$ will only contribute $1.7 \%$ to Indonesia's NDC target from reduced deforestation (out of a potential 23\% under a

12 RBD signatories have committed to reducing deforestation by $80 \%$ in their jurisdictions by 2020, contingent on sufficient financial support (Stickler et al., 2018). full compliance scenario). ${ }^{13}$ At the current pace, only Papua is expected to achieve its RBD target on time, whereas Aceh and Central Kalimantan are projected to reach their targets by 2046 and 2054, respectively. The remaining four provinces are not making progress towards RBD goals at this point (Stickler et al., 2020).

There are three major reasons for the slow progress: lack of funding, entrenched business-as-usual landuse strategies, and vulnerability to electoral processes.

Despite the creation of the GCF-TF to incentivize tropical jurisdictions' participation in California's international offset market (which has yet to materialize), there are low levels of climate funding, and only Norway has responded as a major bilateral donor to support the RBD (Stickler et al., 2020). East Kalimantan is an example of ongoing businessas-usual practices. Its green economic strategy relies on growth from agro-industry and oil palm development (Anderson et al., 2016), and while it promises to protect 640,000 hectares of HCVF - which is arguably inadequate to stop or reverse the exploitative tendency, as a detailed location analysis is lacking - the provincial regulation on sustainable plantation (Perda no. 7/2018) failed to mention this area. Similar trade-offs between conservation and land-based economic development can also be observed in West and Central Kalimantan (LibertAmico and Larson, 2020, Sanders et al., 2019) and in Berau Regency, even with a jurisdictional REDD+ BFCP in place (Anandi et al., 2014b).

As with BP REDD+ at the national level, REDD+ milestones in subnational jurisdictions can be stalled or reversed at each election cycle. For example, Central Kalimantan (the first REDD+ pilot province in Indonesia) saw significantly slower REDD+ progress following the departure of REDD+ champion Governor Teras Narang from office in 2016 (Boyd et al., 2018). In Aceh, continuity of the Ulu Masen REDD+ initiative was uncertain after the end of Governor Irwandi Yusuf's tenure in 2012 (Anandi et al., 2014a). Initiatives implemented around individual champions are not necessarily embedded in the subnational and national government systems; although they can bring about rapid progress initially, the sustainability of such initiatives is uncertain (Luttrell et al., 2018). This is further illustrated in East Kalimantan, where

13 All Indonesian provincial members of GCF Task Force are also signatories to the RBD. 
the implementation of REDD+ green economy reforms (Kaltim Green), and other climate initiatives are managed and coordinated by an ad hoc MSF called the Regional Council on Climate Change (DDPI), established in 2011. DDPI, together with the central government, has played an important role in the preparation and upcoming implementation of the FCPF Carbon Fund. Yet, DDPI's existence is threatened because the Governor Decree (pergub) that established it could be nullified by Governor Ishak's successor (CIFOR, 2019c). There was also pressure to merge DDPI into a structural provincial agency at the beginning of Governor Isran Noor's tenure in 2018. Thus far, DDPI has avoided dissolution because a consolidation of provincial actors have managed to persuade the governor to keep it intact. In summary, leaders with 'green' vision are crucial in starting and driving REDD+ transformations and low-emission development reforms, but meaningful reforms take time and require solid multistakeholder collaboration (Tamara et al., forthcoming). Just like at the national level, governance mechanisms for REDD+ and other climate mitigation initiatives should be structurally and institutionally embedded to ensure long-term outcomes.

\section{Multilevel governance for REDD+: Lessons from multistakeholder forums}

One critical factor to ensuring the success of REDD + and other forest-based climate initiatives is to bring together a large number of actors involved in forest and land-use decision making. MSFs can provide a space for these diverse stakeholders, each with different motivations and interests, to negotiate, and achieve common goals and, ultimately, transformational change (Sarmiento Barletti and Larson, 2019).

Two factors contribute to the effectiveness of MSFs in reaching their intended outcomes: legitimacy and the ability to build trust and cooperation. Legitimacy in this case refers to the extent that others believe an institution has the right to authority (Myers et al., 2018). East Kalimantan's DDPI is one example of a MSF with a high level of legitimacy, because it was led by a respected academic with strong local knowledge (CIFOR, 2019c). In terms of trust building and cooperation, Jambi's adaptive co-management MSF provided local communities with sufficient capacity building to enable active participation. For instance, women were trained separately prior to their involvement in larger MSF discussions, in order to boost their confidence to speak up in a mixed gender setting (CIFOR, 2019a). Similarly, the facilitator of Citarum

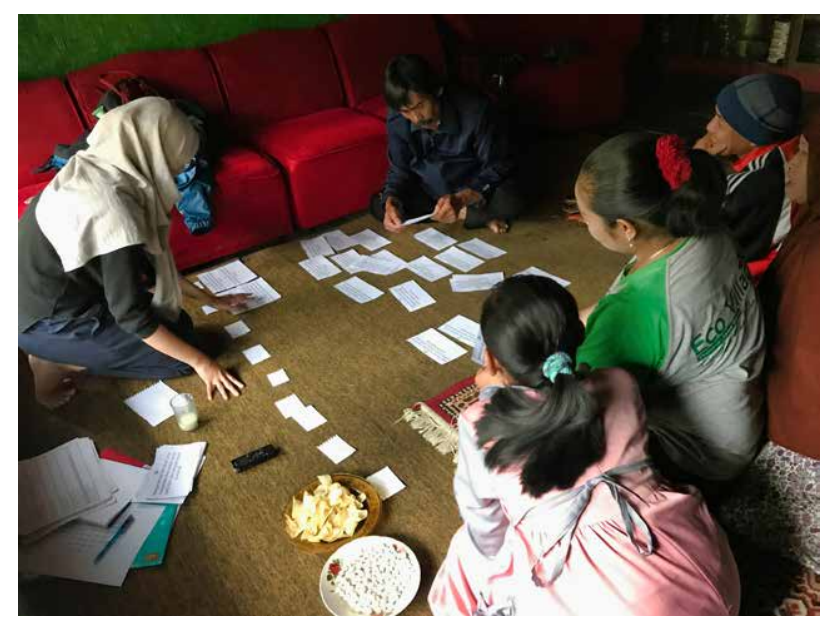

MSF project data collection using Q-method at community level in Pangalengan sub-district, West Java.

Photo by Ade Tamara/CIFOR

River's subdistrict-level (kecamatan) MSF in West Java established an informal relationship with local farmers, leading to positive contributions to its agroforestry project outcomes (CIFOR, 2019b).

However, 'sectoral ego'14 remains a major barrier to MSF effectiveness. This was particularly evident in Citarum watershed's national-level MSF (CIFOR, 2019b), where different ministries prioritized their own programs over the MSF's objective to improve the synergy between various multilevel initiatives and the watershed condition. Now, six years after the project's completion, Citarum River remains one of the most polluted rivers in the world.

\section{Conclusion: Lessons learned for REDD+ and other forest-based climate initiatives}

Indonesia's early involvement in REDD+ has led to a better understanding of the underlying drivers of deforestation and forest degradation in the country, and progress at multiple levels. But the pace has been slower than initially envisioned.

14 Sectoral ego, or ego sektoral in Bahasa Indonesia, refers to a feeling of pride in one's own institution. This has often led institution staff to prioritize their organizational interests and to reject collaboration if it was perceived to jeopardize the institution's priorities. 
Indonesia's initial progress was attributed to early presidential backing and massive international support. But REDD+ lost its momentum due to ministerial reorganization under the Widodo government in 2014. Similar turbulence due to changes in political administration was seen at subnational levels. Learning from this experience, emissions reduction initiatives should be embedded in national and regional laws, regulations, institutions and other state devices to ensure their longevity. This will require proper global market signals for sustainability, as well as substantial mobilization and support from all political agents (e.g. parliament, businesses, government agents, NGOs and the broader public) - as seen in East Kalimantan, where actors mobilized to prevent the disbandment of DDPI. Further, the transfer of power and knowledge from an ad hoc institution to structural ministries needs to be done gradually to maintain a stable progression towards REDD+ objectives.

Power and authority on REDD+ (post BP REDD+) are now concentrated in KLHK, but REDD+ institutionalization has focused mostly on technical aspects, thereby diverting the main focus from addressing socioeconomic and political drivers of deforestation and forest degradation. Although recent reductions in deforestation were sufficient for the country to gain two REDD+ payments, transformational change in the forestry and broader landuse sector is still elusive.

At the subnational level, REDD+ has progressed by varying degrees. To date, the most advanced jurisdiction (East Kalimantan) has sufficient political backing, adequate human and technical capacity, strong international support and optimum engagement with all stakeholders. But even this province is struggling to balance fulfilling economic growth from natural resource exploitation and fulfilling conservation goals associated with REDD+. Private sector sustainability initiatives to support REDD+ are not without some resistance from government actors. Finally, the country has yet to harmonize (or nest) project-level REDD+ emissions reductions with those achieved at higher jurisdictional levels.

We have highlighted that REDD+ and other land-use initiatives are inherently multilevel and multisectoral processes. Successful REDD+ progress is thus also contingent upon the ability of stakeholders to navigate between government levels and across all sectors that impact forests, including building partnerships with nonstate actors. More inclusivity and transparency in forest governance, and placing greater value on forests for the essential ecosystem services and livelihood benefits that they provide, can help Indonesia achieve its climate and sustainable development goals.

\section{Acknowledgments}

The authors thank Stibniati Atmadja, Rupesh Bhomia, Amy Duchelle, Cecilia Luttrell, Rodd Myers, and Swetha Peteru for their helpful comments on earlier versions of this brief, as well as those of researchers at the Forestry and Environment Research Development and Innovation Agency (FORDA), Ministry of Environment and Forestry. We thank Erin O'Connell for language editing support. This research is part of CIFOR's Global Comparative Study on REDD+ (www.cifor.org/gcs). The funding partners that have supported this research include the Norwegian Agency for Development Cooperation (Norad), the Australian Department of Foreign Affairs and Trade (DFAT), the European Commission (EC), the International Climate Initiative (IKI) of the German Federal Ministry for the Environment, Nature Conservation, Building and Nuclear Safety (BMUB), the United Kingdom Department for International Development (UKAID), and the CGIAR Research Program on Forests, Trees and Agroforestry (CRPFTA), with financial support from the donors contributing to the CGIAR Fund.

\section{References}

Anandi AM, Rosudarmo IAP, Ekaputri AD, Komalasari M, Astri P and Aryani R. 2014a, Ulu Masen REDD+ initiative Aceh Indonesia. In Sills EO, Atmadja SS, De Sassi C, Duchelle AE, Kweka DL, Resosudarmo IAP and Sunderlin WD (eds). REDD+ on the ground: A case book of subnational initiatives across the globe. Bogor, Indonesia: Center for International Forestry Research (CIFOR).

Anandi CAM, Resosudarmo IAP, Komalasari M, Ekaputri AD and Intarini DY. 2014b. TNC's initiative within the Berau Forest Carbon Program East Kalimantan Indonesia In Sills EO, Atmadja SS, De Sassi C, Duchelle AE, Kweka DL, Resosudarmo IAP and Sunderlin WD (eds). REDD+ on the ground: A case book of subnational initiatives across the globe. Bogor, Indonesia: CIFOR.

Anderson ZR, Kusters K, McCarthy J and Obidzinski K. 2016. Green growth rhetoric versus reality: Insights from Indonesia. Global Environmental Change 38:30-40.

Angelsen A, Martius C, De Sy V, Duchelle AE, Larson AM and Pham T. 2018. Introduction: REDD+ enters its second decade In Angelsen A, Martius C, De Sy V, Duchelle AE, Larson AM and Pham $T$ (eds). Transforming REDD+: Lessons and New Directions. Bogor, Indonesia: CIFOR. Angelsen A, Streck C, Peskett L, Brown J, and Luttrell C. 2008. What is the right scale for REDD? In Angelsen A (ed). Moving Ahead with REDD: Issues Options and Implications. Bogor, Indonesia: CIFOR. 
Astuti R and McGregor A. 2015. Responding to the green economy: How REDD+ and the One Map Initiative are transforming forest governance in Indonesia. Third World Quarterly 36:2273-2293.

Astuti R and McGregor A. 2016. Indigenous land claims or green grabs? Inclusions and exclusions within forest carbon politics in Indonesia. The Journal of Peasant Studies 44:445-466.

Atmadja SS, Arwida S, Martius C and Pham T. 2018. Financing REDD+: A transaction among equals or an uneven playing field? In Angelsen A, Martius C, De Sy V, Duchelle AE, Larson AM and Pham $\Pi$ (eds). Transforming REDD+: Lessons and New Directions. Bogor, Indonesia: CIFOR.

Barr C, Resosudarmo IAP, McCarthy J and Dermawan A. 2006. Forests and decentralization in Indonesia: An overview. In Barr C, Resosudarmo IAP, Dermawan A, McCarthy J, Moeliono M and Setiono B (eds). Decentralization of Forest Administration in Indonesia: Implications for Forest Sustainability Economic Development and Community Livelihoods. Bogor, Indonesia: CIFOR.

Boyd W Stickler C, Duchelle AE, Seymour F, Nepstad D, Bahar NHA and Rodriguez-Ward D. 2018. Jurisdictional approaches to REDD+ and low emissions development: Progress and prospects. Washington DC: World Resources Institute

Brockhaus M, and Angelsen A,. 2012. Seeing REDD+ through 4Is: a political economy framework. In Angelsen A, Brockhaus M, Sunderlin WD, and Verchot LV (eds). Analysing REDD+: Challenges and Choices. Bogor, Indonesia: CIFOR.

Caldecott J. 2019. The Indonesia-Norway REDD+ partnership. Oryx 53:214-215.

Caldecott J, Mahaningtyas A, Howard B, Williams D and Lincoln P. 2018. Third independent review of the Indonesian-Norway cooperation on reducing greenhouse gas emissions from REDD+. Edinburgh UK: LTS Internationa.I

[CIFOR] Center for International Forestry Research. 2019a. The Adaptive Collaborative Management Multi-Stakeholder Forum: Jambi Indonesia. Bogor, Indonesia: CIFOR. https:// www.cifor.org/knowledge/publication/7453

[CIFOR]. 2019b. The Integrated Citarum Water Resources Management Investment Program Multi-Stakeholder Forums: West Java Indonesia. Bogor, Indonesia: CIFOR. https://www.cifor.org/knowledge/publication/7452/

[CIFOR]. 2019c. Provincial Council on Climate Change: East Kalimantan Indonesia. Bogor, Indonesia: CIFOR. https://www.cifor.org/knowledge/publication/7434/

Di Gregorio M, Brockhaus M, Cronin T and Muharrom E. 2012. Politics and power in national REDD+ policy processes, In Angelsen A, Brockhaus M, Sunderlin WD, and Verchot LV (eds). Analysing REDD+: Challenges and choices. Bogor, Indonesia: CIFOR.

Di Gregorio M, Brockhaus M, Cronin T, Muharrom E, Mardiah S and Santoso L. 2015. Deadlock or transformational change? Exploring public discourse on REDD+ across seven countries. Global Environmental Politics 15:63-84.

Duchelle AE, Seymour F, Brockhaus M, Angelsen A, Larson AM, Moeliono M, Wong GY, Pham TT and Martius C. 2019. Forest-based climate mitigation: Lessons from REDD implementation. Washington DC: World Resources Institute.

Ekawati S, Subarudi Budiningsih K, Sari GK and Muttaqin MZ. 2019. Policies affecting the implementation of REDD+ in Indonesia (cases in Papua Riau and Central Kalimantan). Forest Policy and Economics 108.

Erbaugh JT and Nurrochmat DR. 2019. Paradigm shift and business as usual through policy layering: Forestrelated policy change in Indonesia (1999-2016). Land Use Policy 86: 136-146.

Hovani L, Cortez R, Hartanto H, Thompson I, Fishbein G, Madeira EM and Adams J. 2018. The role of jurisdictional programs in catalyzing sustainability transitions in tropical forest landscapes. Arlington VA: The Nature Conservancy.

[ICEL] Indonesian Center for Environmental Law. 2020. Berbagai Problematika Dalam UU Cipta Kerja Sektor Lingkungan dan Sumber Daya Alam Jakarta. Indonesia: Indonesian Center for Environmental Law.

[IFC] International Finance Corporation. 2018. Prospective development pathways: Private sector engagement in landscape approaches to reduce emissions from land use activities in Jambi province. Jakarta, Indonesia: International Finance Corporation. Indrarto GB, Murhajanti P, Khatarina J, Pulungan I, Ivalerina F, Rahman J, Prana MN, Resosudarmo IAP and Muharrom E. 2012. The context of REDD+ in Indonesia: Drivers agents and institutions. Working Paper 92. Bogor, Indonesia: CIFOR.

Indriatmoko Y, Atmadja SS, Ekaputri AD and Komalasari M. 2014a. Rimba Raya Biodiversity Reserve Project Central Kalimantan Indonesia. In Sills EO, Atmadja SS, De Sassi C, Duchelle AE, Kweka DL, Resosudarmo IAP and Sunderlin WD (eds). REDD+ on the Ground: A Case Book of Subnational Initiatives Across the Globe. Bogor, Indonesia: CIFOR.

Indriatmoko Y, Atmadja SS, Utomo NA, Ekaputri AD and Komalasari M. 2014b. Katingan Peatland Restoration and Conservation Project, Central Kalimantan Indonesia. In Sills EO, Atmadja SS, De Sassi C, Duchelle AE, Kweka DL. Resosudarmo IAP and Sunderlin WD (eds). REDD+ on the Ground: A Case Book of Subnational Initiatives Across the Globe. Bogor, Indonesia: CIFOR.. 
Innovation Forum. 2016. Did the Indonesian palm oil pledge fail or succeed? Innovation Forum, 7 July 2016. https://wwwinnovationforumcouk/articles/did-theindonesian-palm-oil-pledge-fail-or-succeed

Irawan S, Widiastomo T, Tacconi L, Watts JD and Steni B. 2019. Exploring the design of jurisdictional REDD+: The case of Central Kalimantan Indonesia. Forest Policy and Economics 108

Jong HN. 2020a. Deregulation in Indonesia: Economy first, environment later. Maybe. Mongabay, 24 February 2020. https://news.mongabay.com/2020/02/indonesiaomnibus-law-deregulation-environment-economy/

Jong HN. 2020b. Experts question integrity of Indonesia's claim of avoided deforestation. Mongabay, 8 September 2020. https://news.mongabay.com/2020/09/greenclimate-fund-indonesia-redd-deforestation/

Kemenkeu 2020. Indonesia gained trusts: GCF approved USD 103,8 M Indonesia's REDD+ results-based payment proposal. Jakarta, Indonesia: Fiscal Policy Agency, Ministry of Finance. https://fiskal.kemenkeu.go.id/ nda_gcf/en/publications/indonesia-gained-trusts-gcfapproved-usd-103-8-m-indonesia-s-redd-results-basedpayment-proposal

KLHK. 2018a. Indonesia report on REDD+ performance. Jakarta, Indonesia: Directorate General of Climate Change, Ministry of Environment and Forestry.

KLHK. 2018b. The state of Indonesia's forests. 2018. Jakarta, Indonesia: Ministry of Environment and Forestry

Korhonen-Kurki K, Brockhaus M, Bushley B, Babon A, Gebara MF, Kengoum F, Pham T, Rantala S, Moeliono M, Dwisatrio B and Maharani C. 2015. Coordination and cross-sectoral integration in REDD+: Experiences from seven countries. Climate and Development 8:458-471.

Korhonen-Kurki K, Brockhaus M, Muharrom E, Juhola S, Moeliono M, Maharani C and Dwisatrio B. 2017. Analyzing REDD+ as an experiment of transformative climate governance: Insights from Indonesia.

Environmental Science and Policy 73:61-70.

Korhonen-Kurki K, Brockhaus M, Sehring J, Di Gregorio M, Assembe-Mvondo S, Babon A, Bekele M, Benn V, Gebara MF, Kambire HW, Kengoum F, Maharani C, Menton M, Moeliono M, Ochieng R, Paudel NS, Pham T, Dkamela GP and Sitoe A. 2018. What drives policy change for REDD+? A qualitative comparative analysis of the interplay between institutional and policy arena factors. Climate Policy 19:315-328.

Lee D, Llopis P, Waterworth R, Roberts G and Pearson T. 2018. Approaches to REDD+ Nesting: Lessons Learned from Country Experiences. Washington DC: The World Bank.

LI TM. 2015. Governing rural Indonesia: Convergence on the project system. Critical Policy Studies 10:79-94.

Libert-Amico A and Larson AM. 2020. Forestry decentralization in the context of global carbon priorities: New challenges for subnational governments. Frontiers in Forests and Global Change 3.

Luttrell C, Komarudin H, Zrust M, Pacheco P, Limberg G, Nurfatriani F, Wibowo LR, Hakim I and Pirard R. 2018. Implementing sustainability commitments for palm oil in Indonesia: Governance arrangements of sustainability initiatives involving public and private actors. Working Paper 241. Bogor, Indonesia: CIFOR.

Luttrell C, Loft L, Gebara MF and Kweka DL. 2012. Who should benefit and why? Discourses on REDD+ benefit sharing. In Angelsen A, Brockhaus M, Sunderlin WD, and Verchot $L$ (eds). Analysing REDD+: Challenges and Choices. Bogor, Indonesia: CIFOR.

Luttrell C, Resosudarmo IAP, Muharrom E, Brockhaus M, and Seymour F,. 2014. The political context of REDD+ in Indonesia: Constituencies for change. Environmental Science and Policy 35:67-75.

Martius C, Angelsen A, Larson AM, Pham TT, Sonwa DJ and Belcher B. 2018. Pathway to impact: Is REDD+ a viable theory of change? In Angelsen A, Martius C, De Sy V, Duchelle AE, Larson AM and Pham $T$ (eds). Transforming REDD+: Lessons and New Directions. Bogor, Indonesia: CIFOR.

Moeliono M, Brockhaus M, Gallemore C, Dwisatrio B, Maharani CD, Muharrom E and Pham TT. 2020. REDD+ in Indonesia: A new mode of governance or just another project? Forest Policy and Economics 121. Moeliono M, Pham TT, Waty Bong I, Wong GY and Brockhaus M. 2017. Social Forestry - Why and for whom? A comparison of policies in Vietnam and Indonesia. Forest and Society 1.

Murdiyarso D, Dewi S, Lawrence D and Seymour F. 2011. Indonesia's forest moratorium: A stepping stone to better forest governance? Working Paper 76. Bogor, Indonesia: CIFOR.

Myers R and Ardiansyah F. 2014. Who holds power in land-use decisions? Implications for REDD+ in Indonesia. CIFOR Infobrief no 100. Bogor, Indonesia: CIFOR.

Myers R, Larson AM, Ravikumar A, Kowler LF, Yang A and Trench T. 2018. Messiness of forest governance: How technical approaches suppress politics in REDD+ and conservation projects. Global Environmental Change 50:314-324.

Ochieng RM, Arts B, Brockhaus M and Visseren-Hamakers IJ. 2018. Institutionalization of REDD+ MRV in Indonesia Peru and Tanzania: Progress and implications. Ecology and Society 23.

Pacheco P, BAKHTARY H, Camargo M, Donofrio S, Drigo I and Mithöfer D. 2018. The private sector: Can zero deforestation commitments save tropical forests? In Angelsen A, Martius C, De Sy V, Duchelle AE, Larson AM, 
and Pham TT, (eds). Transforming REDD+: Lessons and New Directions. Bogor, Indonesia: CIFOR.

Pirard R, Gnych S, Pacheco P and Lawry S. 2015. Zero deforestation commitments in Indonesia: Governance challenges. Infobrief no 132. Bogor, Indonesia: CIFOR.

Pirard R, Rivoalen C, Lawry S, Pacheco P and Zrust M. 2017. A policy network analysis of the palm oil sector in Indonesia: What sustainability to expect? Bogor, Indonesia: CIFOR.

Resosudarmo IAP, Atmadja SS, Utomo NA, Pratama $C D$, Ekaputri AD, Murray JP, Putri AAD, Agustavia M, Anandi CAM, Aryani R, et al. 2014. REDD+ in Indonesia: The national context. In Sills EO, Atmadja SS, De Sassi C, Duchelle AE, Kweka DL, Resosudarmo IAP and Sunderlin WD (eds). REDD+ on the Ground: A Case Book of Subnational Initiatives Across the Globe. Bogor, Indonesia: CIFOR.

Sanders AJP, Ford M, Mulyani L, Prasti HRD, Larson AM, Jagau Y and Keenan RJ. 2019. Unrelenting games: Multiple negotiations and landscape transformations in the tropical peatlands of Central Kalimantan Indonesia. World Development 117:196-210.

Sarmiento Barletti JP and Larson AM. 2019. The role of multistakeholder forums in subnational jurisdictions: Framing literature review for in-depth field research. Occasional Paper 194. Bogor, Indonesia: CIFOR.

Seymour F. 2012. Indonesia's forest moratorium: The politics of the possible. In Angelsen A, Brockhaus M, Sunderlin WD, and Verchot L (eds). Analysing REDD+: Challenges and Choices. Bogor, Indonesia: CIFOR.

Seymour F,. 2019. Indonesia reduces deforestation, Norway to pay up. 21 February 2019. [Blog] World
Resources Institute https://www.wri.org/blog/2019/02/ indonesia-reduces-deforestation-norway-pay.

Sills EO, Atmadja SS, De Sassi C, Duchelle AE, Kweka DL, Resosudarmo IAP, and Sunderlin WD, (eds). 2014. REDD+ on the Ground: A Case Book of Subnational Initiatives Across the Globe. Bogor, Indonesia: CIFOR.

Simonet G, Karsenty A, Newton P, De Perthuis C, Schaap $B$ and Seyller C. 2015. REDD+ projects in 2014: An overview based on a new database and typology. Information and Debate Series No 32. Paris France: Paris-Dauphine University Climate Economics Chair.

Stickler C, David O, Chan C, Ardila JP and Bezerra T. 2020. The Rio Branco Declaration: Assessing progress toward a near-term voluntary deforestation reduction target in subnational jurisdictions across the tropics. Frontiers in Forests and Global Change 3.

Stickler C, Duchelle AE, Ardila JP, Nepstad D, David O, Chan C, Rojas JG, Vargas R, Bezerra T, Pritchard L, et al. 2018. The state of jurisdictional sustainability: Synthesis for practitioners and policymakers. San Franscisco CA and. Bogor, Indonesia: Earth Innovation Institute and CIFOR.

Tacconi $L$ and Muttaqin MZ. 2019. Reducing emissions from land use change in Indonesia: An overview. Forest Policy and Economics 108:1-7.

Tamara AR, Vigil NMH, Liswanti N, Arwida S, Larson AM and Sarmiento Barletti JP, forthcoming. Trust building and leadership in multistakeholder forums: Lessons from Indonesia. International Forestry Review.

Wertz-kanounnikoff S and Kongphan-Apirak M. 2009. Emerging REDD+: A preliminary survey of demonstration and readiness activities. CIFOR Working Paper. Bogor, Indonesia: CIFOR. 
This research was carried out by CIFOR-ICRAF as part of the CGIAR Research Program on Forests, Trees and Agroforestry (FTA). FTA is the world's largest research for development program to enhance the role of forests, trees and agroforestry in sustainable development and food security and to address climate change. CIFOR leads FTA in partnership with Bioversity International, CATIE, CIRAD, INBAR, ICRAF and TBI.

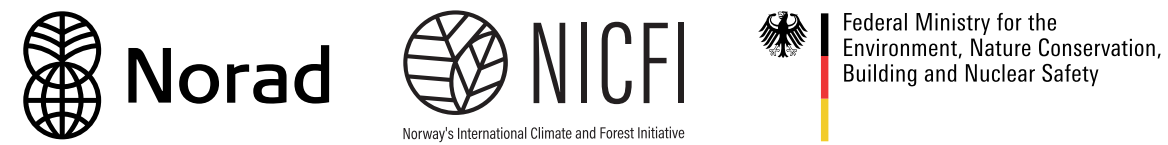
partners' capacity, and actively engaging in dialogue with all stakeholders to inform policies and practices that affect forests and people. CIFOR is a CGIAR Research Center, and leads the CGIAR Research Program on Forests, Trees and Agroforestry (FTA). Our headquarters are in Bogor, Indonesia, with offices in Nairobi, Kenya; Yaounde, Cameroon; Lima, Peru and Bonn, Germany. 